International Journal of Computational and Theoretical Chemistry
2016; 4(2): $7-13$
http://www.sciencepublishinggroup.com/j/ijctc
doi: $10.11648 / \mathrm{j} .1 \mathrm{j}$ ctc.20160402.11
ISSN: $2376-7286$ (Print); ISSN: $2376-7308$ (Online)

\title{
A Statistical Approach to Optimization of Congo Red Dye Removal (CRDR) Via Coconut Shell Activated Carbon (CSAC)
}

\author{
Adepoju Tunde Folorunsho, Ukpong Anwana Abel*, Eyibio Uduak Promise \\ Chemical and Petrochemical Engineering Department, Akwa-Ibom State University, Ikot Akpaden, Mkpat Enin L.G.A, Nigeria
}

\section{Email address:}

anwana.abel@gmail.com (U. A. Abel), anwanaukpong@aksu.edu.ng (U. A. Abel)

${ }^{*}$ Corresponding author

\section{To cite this article:}

Adepoju Tunde Folorunsho, Ukpong Anwana Abel, Eyibio Uduak Promise. A Statistical Approach to Optimization of Congo Red Dye Removal (CRDR) Via Coconut Shell Activated Carbon (CSAC). International Journal of Computational and Theoretical Chemistry.

Vol. 4, No. 2, 2016, pp. 7-13. doi: 10.11648/j.ijctc.20160402.11

Received: October 20, 2016; Accepted: November 4, 2016; Published: December 20, 2016

\begin{abstract}
The use of low-cost, locally available, highly efficient and eco-friendly adsorbents has been investigated as an ideal alternative to the current expensive methods of removing dyes from waste water. The aim of this work was the production of coconut shell activated carbon of Congo Red (CR) dye from aqueous solution. Batch adsorption studies were carried out by observing the effects of temperature and time, and the optimal experimental conditions were ascertained. Variables such as the adsorbent dose, initial concentration of solution and $\mathrm{pH}$ of solution were kept constant at $1 \mathrm{~g}, 100 \mathrm{mg} / \mathrm{L}$ and 7, respectively. The adsorptive capacity and percentage colour removal was mathematically described as a function of experimental parameters and was modelled through central composite response surface methodology (CCRSM). Results showed that the adsorption capacity and the percentage colour removal increased with an increase in time and temperature. The statistical predicted optimum values were validated by carrying out three experiments and an average Congo red (CR) of $86.82 \%$ and adsorption capacity (AC) of 8.50 $\mathrm{mg} / \mathrm{l}$ were obtained at a time $\left(\mathrm{X}_{1}\right)=-1$ and a temperature $\left(\mathrm{X}_{2}\right)=-1$. The coefficient of determination $\left(\mathrm{R}^{2}\right)$ and $\mathrm{R}-\mathrm{Sq}$. (adj.) for CR found in this study were $98.28 \%$ and $97.05 \%$, while that for $\mathrm{AC}$ were $87.85 \%$ and $79.16 \%$, respectively. Thus, the study concluded that the adsorbent was found to be effective, viable and suitable for the removal of Congo Red Dye from aqueous solution and its statistical analysis increased its optimum yields.
\end{abstract}

Keywords: Coconut Shell Activated Carbon (CSAC), Congo Red (CR) Dye, Response Surface Methodology (RSM), Adsorptive Capacity, Colour Removal, Batch Absorption

\section{Introduction}

Dyes have long been used in dyeing, paper and pulp, textiles, plastics, leather, cosmetics and food industries but the effluents discharged from these industries pose certain hazards and environmental problems and the first contaminant that are easily recognizable from these industrial wastewater are colour compounds [1]. These coloured compounds are not only aesthetically displeasing but also inhibit sunlight penetration into the water bodies, thus affecting the aquatic ecosystem and some of these dyes can cause allergic dermatitis, skin irritation, cancer and mutation in man [2]. Recent estimates indicates that approximately $12 \%$ of synthetic textile dyes used each year is lost during manufacture and processing operation and $20 \%$ of these dyes enter the environment through effluents that result from the treatment of residual industrial waters [3]. Dyes usually have complex aromatic molecular structures which makes them more stable and difficult to bio-degrade. Furthermore, many dyes are toxic to some microorganisms and may cause direct destruction or inhibition of their catalytic capabilities.

Textile industries use dye and pigments to colour their products and the dye effluents are highly coloured with a large amount of suspended organic solids [4]. Many types of dye are used in textile industries such as direct, reactive, acid and basic dyes, however, basic dyes are found to be the brightest class of soluble dyes used by the textile industry as their tinctorial value is very high [2]. The various conventional methods of 
removing dyes from wastewater include coagulation and flocculation [5], advanced chemical oxidation [6], electrochemical oxidation [7], ozonation [8], Nano-filtration [9], membrane separation [8], aerobic and anaerobic degradation using various microorganisms, reverse osmosis and adsorption using different kinds of adsorbents [10].

Activated carbons are the most popular adsorbents used for the removal of toxic substances from water and this is as a result of their extended surface area, high adsorption capacity, micro-porous structure and special surface reactivity. However, the adsorptive capacity of activated carbon depends mainly on the precursor nature, the operating conditions of adsorption and the nature of the adsorbate. The carbon precursors may be of botanical origin (wood, coconut shells and fruit seeds), mineral origin (coal, peat) or polymeric materials (rubber, tyres and plastics). About $50 \%$ of industrially available activated carbons are derived from precursors of lingo-cellulosic origin. The production of activated carbon consists of two phases: Carbonization and Activation [11].

The carbonization process includes drying and heating to separate by-products including tars and other hydrocarbons from the raw materials as well as drive off any gases generated. The carbonization process is completed by heating the materials at $400-700{ }^{\circ} \mathrm{C}$ in an oxygen deficient atmosphere that cannot support combustion. After the carbonization, the particles are activated by exposing them to an oxidizing agent usually Steam or Carbon dioxide at high temperature [12]. This agent burns off the pore blocking structure created during carbonization phase and so, they develop a porous, threedimensional graphite lattice structure. The size of the pores developed during activation is a function of the time that they are treated in this stage. This implies that the longer the exposure time, the larger the pore size.

There have been many attempts to find inexpensive and easily available adsorbents to remove pollutants such as agricultural solid wastes where according to their physicochemical characteristics and low cost may be good potential adsorbents [13]. Agricultural wastes are lingocellulosic materials that consist of three main structural components which are lignin, cellulose and hemicelluloses. These components contribute mass and have high molecular weights. Lingo-cellulosic materials also contain extractive structural components which have a smaller molecular size [14]. Agricultural wastes are renewable, available in large amounts and are less expensive as compared to other materials used as adsorbents. Agricultural wastes are better than other adsorbents because agricultural waste is usually used without or with a minimum of processing (washing, drying and grinding) and thus reduce production costs by using cheap raw materials and eliminating energy costs associated with thermal treatment. There are specific alternative agricultural byproducts used intensely as dye adsorbents such as peanut hull, coir pith and rice husk etc. Table 1 shows previous studies of the adsorption of different dyes using adsorbents based on agricultural solid wastes.

Table 1. Previous studies of the adsorption of dye using adsorbents based on agricultural solid wastes.

\begin{tabular}{|c|c|c|}
\hline ADSORBENT & DYE & REFERENCES \\
\hline Sugar beet pulp & Gemazol Turquoise Blue-G & (Aksu and Isoglu, 2006) \\
\hline Powdered peanut hull & Sunset Yellow, Amaranth, Fast Green & (Gong et al., 2005) \\
\hline Rice husk ash & Indigo Carmine & (Lakshmi et al., 2009) \\
\hline Chemically modified peanut hull & Methylene Blue, Brilliant Cresyl Blue, Neutral Red, Sunset Yellow, Fast Green & (Gong et al., 2005) \\
\hline Peanut hull & Methylene Blue, Brilliant Cresyl Blue, Neutral Red & (Gong et al., 2005) \\
\hline Coir pith activated carbon & Reactive Orange 12, Reactive Red 2, Reactive Blue 4 & (Santhy and Salvapathy, 2006) \\
\hline Coir pith activated carbon & Congo Red & (Namasivayam and Sangeetha, 2002) \\
\hline Coir pith carbon & Methylene Blue & (Kavitha and Namasivayam, 2007) \\
\hline $\mathrm{ZnCl} 2$ activated Coir pith carbon & Acid brilliant blue, acid violet, Methylene Blue, Rhodamine B & (Namasivayam and Sangeetha, 2006) \\
\hline Coir pith & Acid Violet & (Namasivayam et al., 2001) \\
\hline Rice husk activated carbon & Malachite Green & (Rahman et al., 2005) \\
\hline Rice husk-based porous carbon & Malachite Green & (Guo et al., 2003) \\
\hline Rice husk & Congo red & (Han et al., 2008) \\
\hline Tea Waste & Methylene Blue & (Uddin et al., 2009) \\
\hline Coniferous pinus bark powder & Crystal Violet & (Ahmad, 2009) \\
\hline Orange peel activated carbon & Direct Blue-106 & (Khaled et al., 2009) \\
\hline Neem sawdust & Malachite Green & (Khattri and Singh, 2009) \\
\hline Guava seed carbon & Acid Blue 80 & $\begin{array}{l}\text { (Elizalde-Gonzalez and Hernandez- } \\
\text { Montoya, 2009) }\end{array}$ \\
\hline Peanut Hull & Reactive Black 5 & (Tanyildizi, 2011) \\
\hline Loofa activated carbon & Reactive Orange & (Abdelwahab, 2008) \\
\hline Lemon peel & Malachite Green & (Kumar, 2007) \\
\hline Bagasses Fly Ash & Methyl Violet & (Mall et al., 2006) \\
\hline
\end{tabular}

(Source: 15)

Hence, the aim of this work is to evaluate the adsorptive capacity of coconut shell based activated carbon on Congo red dye removal from wastewater with specific attention to the production of coconut shell activated carbon as adsorbent, examination of the effects of process variables (temperature: $\mathrm{X}_{1}$ and contact time: $\mathrm{X}_{2}$ ) on the adsorptive capacity of coconut shell activated carbon and percentage colour removal, the formulation of model and determination of optimum 
conditions for adsorptive capacity of the coconut shell activated carbon and percentage colour removal by employing a Central Composite Design (CCD) in Response Surface Methodology (RSM) Design Expert Software Version 10. RSM was selected to elucidate the simultaneous effects of parameters on the adsorption process. The multiple regression analysis technique in the RSM was utilized to develop the equations and empirical models correlating the Congo red dye removal efficiency and Coconut shell activated carbon yield to two adsorption variables. The analysis of variance (ANOVA) was employed to judge the adequacy of the model. The optimized conditions developed from the model were validated experimentally and feasibility of CSAC for CR dye removal was obtained.

\section{Material and Methods}

\subsection{Materials and Reagents Used}

Coconut shell, Congo red dye, Sulphuric acid, Distilled water, Deionized water, Filter paper, Electric furnace, Oven, $\mathrm{P}^{\mathrm{H}}$ Meter, Thermostatic water bath, Mechanical Shaker, UltraViolet Spectrophotometer (UVS), Zinc chloride Solution), $1 \mathrm{M}$ $\mathrm{HCl}, 1 \mathrm{M} \mathrm{NaOH}$ solution and Conical flasks etc.

\subsection{Experimental Procedure}

\subsubsection{Preparation of Adsorbent (Activated Carbon)}

The coconut shell was collected from Itam market, Uyo, Akwa-Ibom State, Nigeria. It was washed with water to remove the debris and then drained overnight. The coconut shell was then crushed in order to increase the surface area and drying rate before it was then dried in an electric oven at a temperature of $105^{\circ} \mathrm{C}$ to remove moisture contained in it. The crushed coconut shell samples were carbonized in a muffle furnace at a temperature of $600^{\circ} \mathrm{C}$ for 1 hour according to the reported method [16] and further crushed and separated into different mesh sizes of (1-2 mm). The separation into different mesh sizes was achieved with the aid of a mechanical sieve. The charcoal was then soaked in activating agent of Zinc chloride solution with a weighed quantity of $500 \mathrm{~g}$ of the samples for $24 \mathrm{~h}$. The samples were then heated in the furnace for activation at activation temperature of $800^{\circ} \mathrm{C}$ for $2 \mathrm{~h}$. After activation, the activated samples were further treated with 0.1 $\mathrm{M} \mathrm{HCl}$ to reduce the ash and mineral content of the samples. The samples were neutralized with $1 \mathrm{M} \mathrm{NaOH}$ solution, rinsed with distilled water until the $\mathrm{pH}$ was almost neutral $(\mathrm{pH} \approx 7)$. The resulting activated carbon was dried in the oven at $110^{\circ} \mathrm{C}$ for $2 \mathrm{~h}$ and then the activated carbon samples were packaged in well-fitted airtight containers which were now ready for adsorption processes.

\subsubsection{Preparation of Adsorbate (Textile Effluent)}

The components of the adsorbate are Deionized water and Congo Red Dye $\left(\mathrm{C}_{32} \mathrm{H}_{22} \mathrm{~N}_{6} \mathrm{Na}_{2} \mathrm{O}_{2} \mathrm{~S}_{2}\right)$ of molecular weight of $696.63 \mathrm{~g} / \mathrm{mol}$ and wavelength $\left(\lambda_{\max }=510 \mathrm{~nm}\right)$. The stock solution was prepared by measuring and dissolving $0.1 \mathrm{~g}$ of
Congo red dye in deionized water and to make up to $1000 \mathrm{~mL}$ which is equivalent to $100 \mathrm{mg} / \mathrm{L}$ of the solution.

\subsubsection{Procedure for Batch Absorption}

For the preliminary batch adsorption process to determine the equilibrium point for the adsorption, a constant $\mathrm{pH}$ of 7.0, constant initial dye concentration $(100 \mathrm{mg} / \mathrm{L})$, constant adsorbent dose of $1 \mathrm{~g} / 100 \mathrm{~mL}$, temperature varied between 30 and $50^{\circ} \mathrm{C}$ and contact time varied between 0.5 and 3 hours $(0.5$, 1.5 and 3 hours), thus allowing sufficient time 3 hours for adsorption equilibrium to be reached.

i. The $\mathrm{pH}$ of the dye solution was measured.

ii. $1 \mathrm{~g}$ of the adsorbent was measured into $100 \mathrm{~mL}$ of 500 $\mathrm{mg} / \mathrm{L}$ dye solution into a $250 \mathrm{~mL}$ corked conical flask.

iii. The $250 \mathrm{~mL}$ flask of adsorbent solution was placed in the thermostatic water bath shaker.

iv. The solution was filtered using Whatman-42 Filter paper and the dye concentration was analysed using Ultra-Violet Spectrophotometer (UVS).

\subsection{Adsorption Studies}

\subsubsection{Effect of Contact Time}

The effect of contact time was studied at ambient temperature of $30^{\circ} \mathrm{C}$. Congo red dye solution of initial concentration of $100 \mathrm{mg} / \mathrm{L}$ was prepared. $100 \mathrm{~mL}$ of the above solution was added to the conical flask containing $1 \mathrm{~g}$ of CSAC for different contact time $(0.5,1.5,3.0$ hours $)$. No $\mathrm{pH}$ adjustment was made as all the studies were carried out at a $\mathrm{pH}$ of 7. After predetermined time interval, the content of the flasks were filtered through Whatman filter paper and the filtrates were analysed for residual Congo red dye concentration using Ultra-violet Spectrophotometer (UVS).

\subsubsection{Effect of Temperature}

To study the effect of temperature on the adsorption of Congo red dye, the Congo red dye solution of initial concentration of $100 \mathrm{mg} / \mathrm{L}$ was prepared. $100 \mathrm{~mL}$ of the solution was poured into the conical flasks and maintained at different temperatures $\left(30\right.$ to $\left.50^{\circ} \mathrm{C}\right)$. To the above solutions, $1 \mathrm{~g}$ of CSAC was added and agitated at $120 \mathrm{rpm}$ for the time intervals stated above. No $\mathrm{pH}$ adjustment was made as all studies were carried out at a $\mathrm{pH}$ of 7 . The content of the flasks were filtered through Whatman filter paper and the filtrates were analysed for residual Congo red dye concentration using Ultra-violet Spectrophotometer (UVS).

\subsection{Analysis of the of Congo Red Dye}

To analysis the Congo red dye, two different analysis was carried out, vis-a-viz adsorptive capacity and percentage colour removal using Eqn. (1) and Eqn. (2).

\subsubsection{Determination of Absorptive Capacity}

This is expressed as:

$$
Q_{t}=\frac{\left(C_{0}-C_{t}\right) V}{x}
$$




\subsubsection{Determination of Percentage Colour Removal}

$$
\% \text { Colour Removal }=\frac{\left(C_{o}-C_{t}\right) \times 100}{C_{o}}
$$

\subsection{Experimental Design}

In this project, design expert software of 10 was used to design the experiments for optimizing the response of the parameters involved in the experiment using Response Surface Methodology (RSM). The dependent variable that was selected for this study was the residual concentration of Congo red dye, expressed in $\mathrm{mg} / \mathrm{L}$ and the independent variables that were chosen were temperature and contact time.

A statistical optimization was conducted by using Central Composite Design (CCD) with two factors. The CCD was used to determine the main and interaction effects of all the process parameters. The low and high level and ranges of all the factors that were studied are given in Table 2.1. The actual values of the process variables and their ranges were selected based on the preliminary experiments. Thirteen (13) experimental runs for removal of Congo red dye were conducted; the experimental design matrixes for the experiments are presented in tabular form. The experimental data was analysed using
Statistical Software (Design expert 6.0.8) to develop the polynomial regression model for determining the optimum condition. The optimum values of all the variables were obtained by solving the regression equations and by analysing the contour and 3D surface plots.

Table 2. Process variable of the design centre points.

\begin{tabular}{lll|ll}
\hline Variable & Symbol & \multicolumn{3}{c}{ Coded factor levels } \\
\hline & & -1 & 0 & +1 \\
Temperature $\left({ }^{\circ} \mathrm{C}\right)$ & $\mathrm{X}_{1}$ & 30 & 40 & 50 \\
Time (hours) & $\mathrm{X}_{2}$ & 0.5 & 1.5 & 3.0 \\
\hline
\end{tabular}

\section{Results and Discussion}

In this work, a standard response surface methodology design called central composite design was applied to study the variables (temperature and contact time) for adsorption capacity and percentage colour removal of Congo red dye with coconut shell activated carbon. The adsorption variables used were temperature $\left(\mathrm{X}_{1}\right)$ and time $\left(\mathrm{X}_{2}\right)$ and 13 experiments were conducted. The effect of the central composite design on the percentage colour removal, adsorption capacity, the predicted and the residual values are represented in Table 3.

Table 3. CCD coded arrangement, responses, predicted and the residual values.

\begin{tabular}{|c|c|c|c|c|c|c|c|c|}
\hline Exp. Runs & $\mathrm{X}_{1}\left({ }^{\circ} \mathrm{C}\right)$ & $\mathbf{X}_{2}(\min )$ & CR (\%) & $\mathrm{AC}(\mathrm{mg} / \mathrm{g})$ & \multicolumn{2}{|c|}{ Predicted CR (\%) AC (mg/g) } & \multicolumn{2}{|c|}{ Residual CR (\%) AC (mg/g) } \\
\hline 1 & -1 & -1 & 83.70 & 8.30 & 84.48 & 8.48 & -0.78 & -0.18 \\
\hline 2 & 1 & -1 & 82.00 & 8.10 & 82.33 & 8.20 & -0.33 & -0.096 \\
\hline 3 & -1 & 1 & 89.10 & 8.88 & 89.58 & 8.98 & -0.48 & -0.10 \\
\hline 4 & 1 & 1 & 88.00 & 8.85 & 87.77 & 8.80 & 0.23 & 0.048 \\
\hline 5 & -1 & 0 & 85.00 & 8.70 & 84.48 & 8.48 & 0.52 & 0.22 \\
\hline 6 & 1 & 0 & 86.50 & 8.70 & 86.48 & 8.66 & 0.015 & 0.037 \\
\hline 7 & 0 & -1 & 93.00 & 9.34 & 92.77 & 9.32 & 0.23 & 0.019 \\
\hline 8 & 0 & 1 & 84.70 & 8.50 & 84.48 & 8.48 & 0.22 & 0.020 \\
\hline 9 & 0 & 0 & 91.50 & 9.15 & 91.77 & 9.19 & -0.27 & -0.039 \\
\hline 10 & 0 & 0 & 84.10 & 8.30 & 84.48 & 8.48 & -0.38 & -0.18 \\
\hline 11 & 0 & 0 & 84.90 & 8.60 & 84.48 & 8.48 & 0.42 & 0.12 \\
\hline 12 & 0 & 0 & 87.40 & 8.74 & 87.32 & 8.73 & 0.076 & 0.011 \\
\hline 13 & 0 & 0 & 86.50 & 8.70 & 85.98 & 8.58 & 0.52 & 0.12 \\
\hline
\end{tabular}

Fig. 1(a-b) shows the plots of predicted against the actual for $\mathrm{CR}$ and AC. Observation from the plots shows that the predicted plots perfectly fitted the actual values and the lines passed through the points in a straight line. The results of test of significance for all regression coefficient are presented in Table 4. Observation from the table showed that all p-values of the linear terms $\left(\mathrm{X}_{1}, \mathrm{X}_{2}\right)$, the interaction terms $\left(\mathrm{X}_{1} \mathrm{X}_{2}\right)$ and the quadratic terms $\left(\mathrm{X}_{2}^{2}\right)$ were significant $(\mathrm{p}<0.0001)$ except the quadratic term $\left(\mathrm{X}_{1}{ }^{2}: \mathrm{p}\right.$-value $\left.=0.4274\right)$ that was found to be non-significant for $\mathrm{CR}$. For $\mathrm{AC}$, the $\mathrm{p}$-values for the linear terms $\left(\mathrm{X}_{1}, \mathrm{X}_{2}\right)$ and the quadratic terms $\left(\mathrm{X}_{2}^{2}\right)$ were found to be significant with $\mathrm{p}$-value $<0.05$, while the interaction terms $\left(\mathrm{X}_{1} \mathrm{X}_{2}: \mathrm{p}\right.$-value $\left.=0.3671\right)$ and quadratic term $\left(\mathrm{X}_{1}{ }^{2}: \mathrm{p}\right.$-value $=$ 0.8863 ) were not significant.

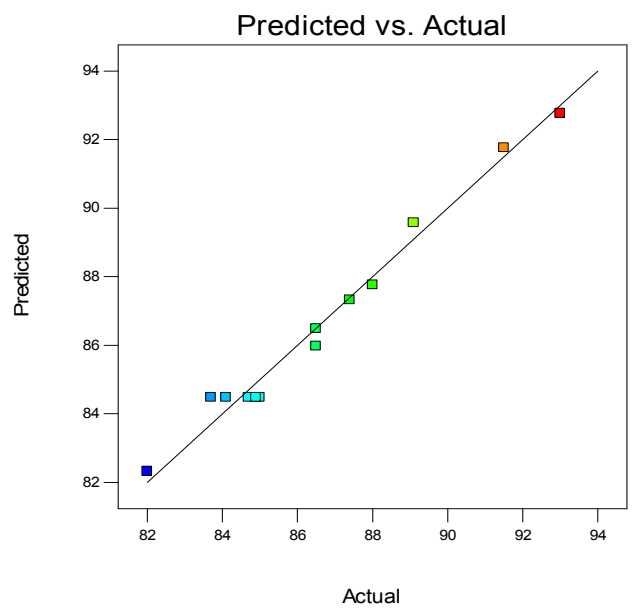

Fig. 1(a). Predicted against Actual for CR. 


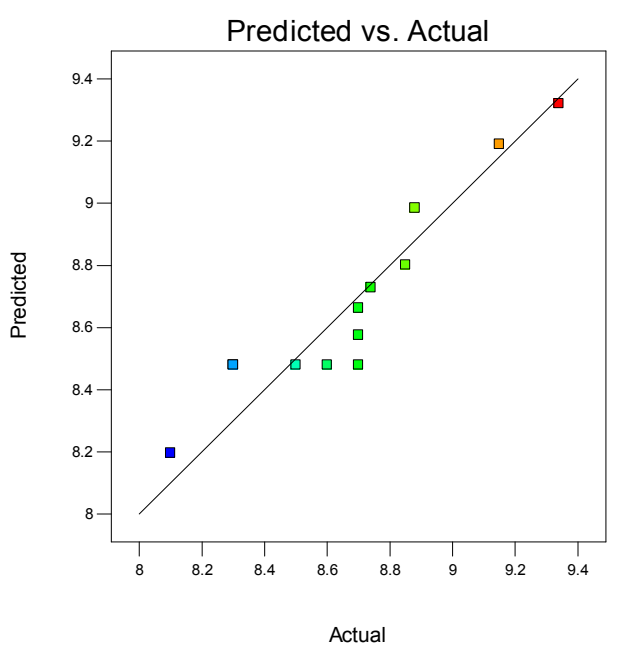

Fig. 1(b). Predicted against Actual for AC.

In order to minimize the error in the process, all the coefficients in the design were considered. Table 5 shows the result for analysis of variance of regression equation. The model F-value of AC (116.65) and CR (1.22) inferred that the models were significant $(\mathrm{p}<0.0001)$. The lack-of-fit for both responses were not significant, this implies that the data obtained fitted best to the quadratic model with low standard deviation $(0.54 ; 0.16)$ and high mean values $(86.65 ; 8.68)$.

Table 4. Test of Significance for Every Regression Coefficient.

\begin{tabular}{llllll}
\hline CR (\%) & & & & & \\
\hline Source & $\begin{array}{l}\text { Sum of } \\
\text { squares }\end{array}$ & df & $\begin{array}{l}\text { Mean } \\
\text { Square }\end{array}$ & $\begin{array}{l}\text { F- } \\
\text { value }\end{array}$ & p-value \\
\hline $\mathrm{X}_{1}$ & 24.98 & 1 & 24.98 & 85.62 & $<0.0001$ \\
$\mathrm{X}_{2}$ & 10.16 & 1 & 10.16 & 34.82 & 0.0006 \\
$\mathrm{X}_{1} \mathrm{X}_{2}$ & 3.06 & 1 & 3.06 & 10.50 & 0.0143 \\
$\mathrm{X}_{1}{ }^{2}$ & 0.21 & 1 & 0.21 & 0.71 & 0.4274 \\
$\mathrm{X}_{2}{ }^{2}$ & 77.95 & 1 & 77.95 & 267.19 & $<0.0001$ \\
\hline AC (mg/l) & & & & & \\
\hline $\mathrm{Source}$ & Sum of & df & Mean & F- & p-value \\
\hline $\mathrm{X}_{1}$ & squares & 1 & 0.28 & 11.70 & 0.0111 \\
$\mathrm{X}_{2}$ & 0.28 & 1 & 0.11 & 4.67 & 0.0676 \\
$\mathrm{X}_{1} \mathrm{X}_{2}$ & 0.022 & 1 & 0.022 & 0.93 & 0.3671 \\
$\mathrm{X}_{1}{ }^{2}$ & $5.326 \mathrm{E}-004$ & 1 & $5.326 \mathrm{E}-004$ & 0.022 & 0.8863 \\
$\mathrm{X}_{2}{ }^{2}$ & 0.79 & 1 & 0.79 & 32.49 & 0.0007 \\
\hline
\end{tabular}

The closer the $\mathrm{R}^{2}$ value to unity, the better the model, as this will give predicted values which are closer to the actual values for the response [17]. The coefficient of determination $\left(R^{2}\right)$ and R-Sq. (adj.) for CR found in this study were $98.28 \%$ and $97.05 \%$, while that for $\mathrm{AC}$ were $87.85 \%$ and $79.16 \%$ respectively. The higher values obtained indicated the suitability of the model for the acceptable illustration for the connection between the two independent factors considered. Table 6 represents the regression coefficients and significance of response surface quadratic, the low values of standard error observed in the intercepts, the independent variable factors, the interactions and the quadratic terms shows that the regression model best fitted the data and this depicts a good prediction. The centre points orthogonally with factors were checked by considering the variance inflation factor and the values obtained ranging from 1.00 to 1.02 were good. The final equation in terms of coded factors considered for the two responses for 13 experimental CCD response surface quadratic models are stated in Eqn. (3) and Eqn. (4).

$$
\begin{gathered}
C R \%=84.48-1.77 X_{1}+1.13 X_{2}-0.88 X_{1} X_{2}+0.17 X_{1}^{2 \cdot}+ \\
3.35 X_{2}^{2} \\
A C(m g / l)=8.48-0.19 X_{1}+0.12 X_{2}-0.075 X_{1} X_{2}- \\
0.00875 X_{1}^{2 \cdot}+0.34 X_{2}^{2}
\end{gathered}
$$

\begin{tabular}{|c|c|c|c|c|c|}
\hline \multicolumn{6}{|l|}{ CR (\%) } \\
\hline Source & $\begin{array}{l}\text { Sum of } \\
\text { squares }\end{array}$ & df & $\begin{array}{l}\text { Mean } \\
\text { Square }\end{array}$ & F-value & p-value \\
\hline Model & 116.65 & 5 & 23.33 & 79.96 & $<0.0001$ \\
\hline Residual & 2.04 & 7 & 0.29 & & \\
\hline Lack of Fit & 0.79 & 3 & 0.26 & 0.85 & 0.5351 \\
\hline Pure Error & 1.25 & 4 & 0.31 & & \\
\hline Cor. Total & 118.69 & 12 & & & \\
\hline \multicolumn{6}{|c|}{ RSM: S.D = 0.54; Mean $=86.65 ;$ R-Sq. $=98.28 \%$, R-Sq. $($ adj. $)=97.05 \%$} \\
\hline \multicolumn{6}{|c|}{$\mathrm{AC}(\mathrm{mg} / \mathrm{l})$} \\
\hline Source & $\begin{array}{l}\text { Sum of } \\
\text { squares } \\
\end{array}$ & df & $\begin{array}{l}\text { Mean } \\
\text { Square }\end{array}$ & F-value & p-value \\
\hline Model & 1.22 & 5 & 0.24 & 10.12 & 0.0042 \\
\hline Residual & 0.17 & 7 & 0.024 & & \\
\hline Lack of Fit & 0.041 & 3 & 0.014 & 0.43 & 0.7420 \\
\hline Pure Error & 0.13 & 4 & 0.032 & & \\
\hline Cor. Total & 1.39 & 12 & & & \\
\hline
\end{tabular}

Table 5. Analysis of Variance (ANOVA) of Regression Equation.

Table 6. Regression coefficients and significance of response surface quadratic.

\begin{tabular}{lllllll}
\hline CR (\%) & & & & & & \\
\hline Factor & $\begin{array}{l}\text { Coefficient } \\
\text { Estimate }\end{array}$ & df & $\begin{array}{l}\text { Standard } \\
\text { Error }\end{array}$ & $\begin{array}{l}\mathbf{9 5 \% C I} \\
\text { Low }\end{array}$ & $\begin{array}{l}\mathbf{9 5 \% C I} \\
\text { High }\end{array}$ & VIF \\
\hline Intercept & 84.48 & 1 & 0.24 & 83.91 & 85.05 & \\
$\mathrm{X}_{1}$ & -1.77 & 1 & 0.19 & -2.22 & -1.32 & 1.00 \\
$\mathrm{X}_{2}$ & 1.13 & 1 & 0.19 & 0.68 & 1.58 & 1.00 \\
$\mathrm{X}_{1} \mathrm{X}_{2}$ & -0.88 & 1 & 0.27 & -1.51 & -0.24 & 1.00 \\
$\mathrm{X}_{1}{ }^{2}$ & 0.17 & 1 & 0.20 & -0.31 & 0.66 & 1.02 \\
$\mathrm{X}_{2}{ }^{2}$ & 3.35 & 1 & 0.20 & 2.86 & 3.83 & 1.02 \\
\hline $\mathbf{A C}$ (mg/l) & & & & & & \\
\hline Factor & Coefficient & df & Standard & $\mathbf{9 5 \% C I}$ & $\mathbf{9 5 \% C I}$ & VIF \\
\hline Intercept & 8.48 & 1 & 0.070 & 8.32 & 8.64 & \\
$\mathrm{X}_{1}$ & -0.19 & 1 & 0.055 & -0.32 & -0.058 & 1.00 \\
$\mathrm{X}_{2}$ & 0.12 & 1 & 0.055 & -0.011 & 0.25 & 1.00 \\
$\mathrm{X}_{1} \mathrm{X}_{2}$ & -0.075 & 1 & 0.078 & -0.26 & 0.11 & 1.00 \\
$\mathrm{X}_{1}{ }^{2}$ & $-8.750 \mathrm{E}-003$ & 1 & 0.059 & -0.15 & 0.13 & 1.02 \\
$\mathrm{X}_{2}{ }^{2}$ & 0.34 & 1 & 0.059 & 0.20 & 0.48 & 1.02 \\
\hline
\end{tabular}

Chart, diagram or graph can be used to provide a kind of pictorial method to discern the responses and to the variable factors considered in this experiment. Fig. 2 ( $a \& b$ ) shows the contours and the 3D's plots representing the effects of 
independent variable factors on both $\mathrm{AC}$ and $\mathrm{CR}$. It was observed that there were mutual interactions among the variables considered on the responses.

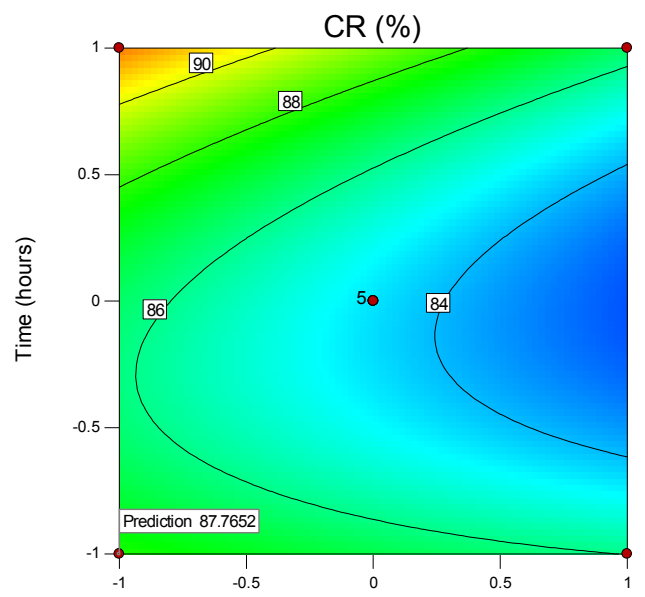

Temperature (deg.C)

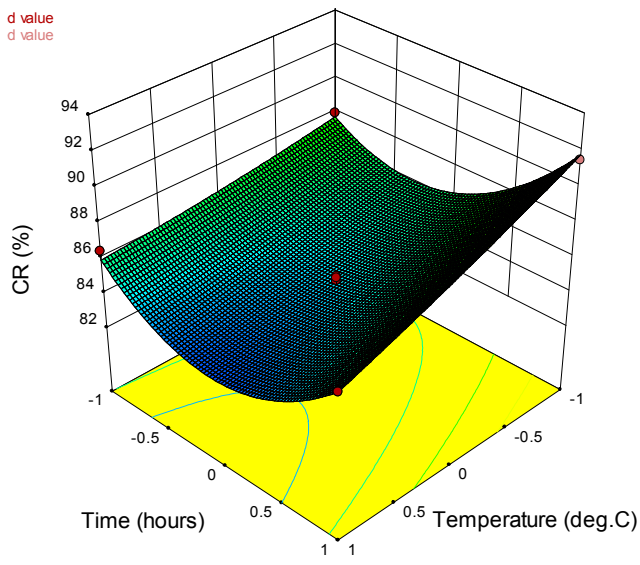

Fig. 2(a). Contour and the $3 D$ plots for $A C$.

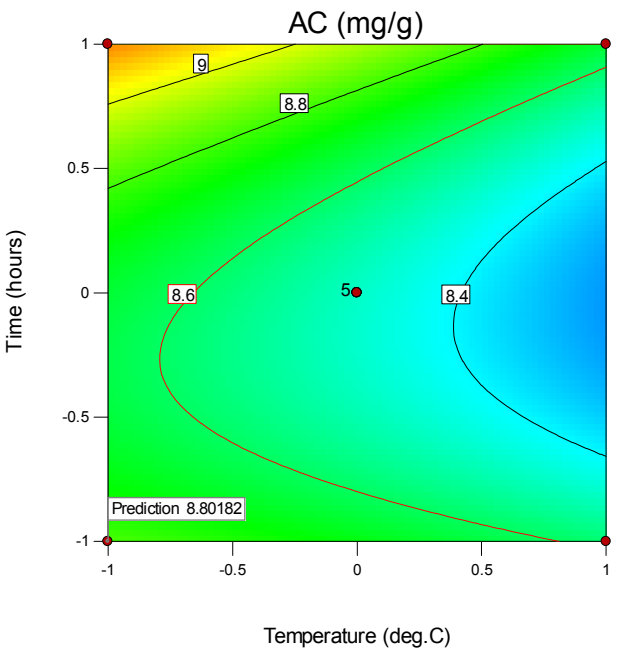

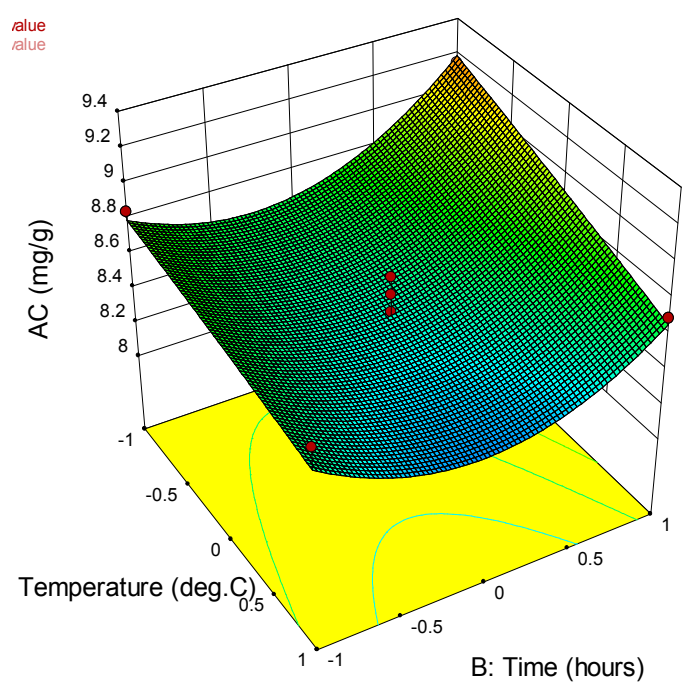

Fig. 2(b). Contour and the 3D's plot for CR.

The highest experimental CR and AC yield were $93.00 \%$ and $9.34 \mathrm{mg} / \mathrm{l}$, respectively at $\mathrm{X}_{1}=0, \mathrm{X}_{2}=-1$, the statistical software predicted CR of $87.765 \%$ and AC of $8.802 \mathrm{mg} / 1$ at $\mathrm{X}_{1}$ $=-1$ and $X_{2}=-1$ variable conditions. Validation of predicted values was confirmed by carrying out three experiments, an average $\mathrm{CR}$ of $86.82 \%$ and $\mathrm{AC}$ of $8.50 \mathrm{mg} / \mathrm{l}$ were obtained, which was well within the predicted ranges.

The results of this study demonstrated the use of coconut shell activated carbon for congo dye red removal and response surface methodology is good statistical software for its optimization.

\section{Conclusion}

In this research project, adsorptive capacity and percentage colour removal of Congo red dye using Coconut shell activated carbon was analysed based on the operating parameters of temperature and time. The experimental design was done using central composite design and the experimental data was analysed to obtain optimum conditions. The coefficient of determination $\left(\mathrm{R}^{2}\right)$ and $\mathrm{R}-\mathrm{Sq}$. (adj.) for $\mathrm{CR}$ were better than that obtained for AC. Hence, the study concludes the suitability of coconut shell activated carbon for colour removal of Congo red dye from wastewater.

\section{References}

[1] Banat, F., Al-Asheh S. and Al-Makhadmeh (2003): "Evaluation of the use of raw and activated date pits as potential adsorbents for dye containing water". Proc. Biochem, 39(2): 193-202.

[2] Hema, M. and Arivoli, S. (2007): "Comparative study on the adsorption kinetics and thermodynamics of dyes onto acid activated low cost carbon". International journal of physical sciences, 2(1): 10-17.

[3] Weber, E. J. and Stickney, V. C. (1993): "Water pollution by synthesis textile dyes". Water Res. 27: 63. 
[4] Okeola, O. F., Odebunmi, E. O. And Bakare, O. F. (2014): "Equilibrium and kinetic studies of adsorption of congo red by activated carbon". Middle-East journal of scientific research. 19(11): 1425-1431.

[5] Liu, R. L. H, Chiu, H. M, Yeh, R. Y. L (2003): “International Journal of Environmental Studies". 59: 143-158.

[6] Arslan, I, Balcoiglu, I. A and Tuhhkanen, T. J (2000): “Journal of Environmental Science Health". 35: 775-793.

[7] Torres R. M, Gutierrez, M. C (2010): “Chemical Engineering Journal". 156, 114-120.

[8] Mahmoud, A. S, Ghaly, A. E and Brooks, M. S (2007): "American Journal of Environmental Sciences". 3(4): 205-218.

[9] Chakraborty, S., Purkait, M. K, DasGupta, S., Basu, J. K (2003): "Separation and Purification Technology". 31, 141-151.

[10] Bilal, A. (2004): "Journal of Colloid and Interface Science". 274, 371-379.

[11] Haimour, N. M, Emeish, S. (2006): "Utilization of date stones for production of activated carbon using Phosphoric acid". Waste Management. 26, 51-60.
[12] Diao, W. P, Fan Walawender, L. T (2002): "Activated carbon prepared from Phosphoric acid activation of grain sorghum". Bioressour Technology. 81, 45-52.

[13] Rafatullah, M., Sulaiman, O., Hashim, R., Ahmad, A. (2010): "Adsorption of methylene blue on low-cost adsorbents: A review”. J. Hazard., Mater., 177: 70-80.

[14] Demirbas, A. (2009): Agricultural based activated carbons for the removal of dyes from aqueous solutions. A review". J. Hazard. Mater., 167: 1-9.

[15] Kyzas, G. Z. and Matis, K. A. (2013): "A change from past to future for adsorbent materials in treatment of dyeing wastewaters: A review”. Materials 6: 5131-5158.

[16] Babel, S. and Kurniawan T. A (2003): "Low-cost adsorbents for heavy metals uptake from contaminated water". Journal of Hazard materials. 97: 219-243.

[17] Ahmad, M. A and Alrozi, R. (2010): "Optimization of preparation conditions for mangosteen peel-based activated carbons for the removal of Remazol Brilliant Blue R using Response Surface Methodology”. Chem. Eng J. 165: 883-890. 